\begin{tabular}{cc|c}
\hline Tar. Bil. Der. & $\begin{array}{c}\text { Tarım Bilimleri Dergisi } \\
\text { Dergi web sayfası: }\end{array}$ & Journal of Agricultural Sciences \\
& $\begin{array}{c}\text { Journal homepage: } \\
\text { www.agri.ankara.edu.tr/dergi }\end{array}$ & www.agri.ankara.edu.tr/journal \\
\hline
\end{tabular}

\title{
Analyzing Variation of Sediment Yields in Wet and Drought Years
}

\section{İran OĞUZ}

${ }^{a}$ Gaziosmanpasa University, Faculty of Agriculture, Department of Soil Science and Plant Nutrition, Tokat, TURKEY

\section{ARTICLE INFO}

Research Article - Natural Resources Management and Landscape Planning DOI: 10.1501/Tarimbil_0000001202

Corresponding Author: İrfan OĞUZ, e-mail: irfanoguz@yahoo.com, Tel: +90(356) 2521616

Received: 19 August 2011, Received in revised form: 24 February 2012, Accepted: 10 December 2012

\begin{abstract}
This study presents meteorological and hydrologic drought effects on sediment yield in a small rural basin, Uğrak Watershed in Tokat Region of North Central Anatolia, Turkey. Sediment yield was estimated by using Modified Universal Soil Loss Equation (MUSLE) model for 25 years period. The maximum and minimum sediment yields were estimated in 1980 and 1997 respectively. Historical precipitation and flow data were analyzed to determine meteorological and hydrological drought by Standardized Precipitation Index (SPI) method. Results showed that there was 10-year drought vs. 15-year wet for meteorological and 14-year drought vs. 11-year wet for hydrological conditions. In the meteorologically drought and wet years, the sediment yields were estimated as 6920.7 tons and 18068.2 tons, respectively. In the hydrological dry and wet years, the sediment yields were estimated as 7417.8 tons and 21489.2 tons, respectively. Sediment yields were found similar in meteorological and hydrological wet and also similar in meteorological and hydrological dry conditions. Drought reduced the sediment yield in the study area.
\end{abstract}

Keywords: MUSLE; GIS; Drought; Sediment yield; Watershed

\section{Yağışlı ve Kurak Yıllarda Sediment Veriminin Değişim Analizi}

\section{ESER BILGISI}

Araştırma Makalesi-Doğal Kaynak Yönetimi ve Peyzaj Planlama

Sorumlu Yazar: İrfan OĞUZ, e-posta: irfanoguz@ yahoo.com, Tel: +90(356) 2521616

Geliş Tarihi: 19 Ağustos 2011, Düzeltmelerin gelişi: 24 Şubat 2012, Kabul: 10 Aralık 2012

\section{ÖZET}

Bu çalışma meteorolojik ve hidrolojik kuraklı̆̆ın küçük bir kırsal havzada, Kuzey Orta Anadolu Bölgesi Tokat İli Uğrak Havzası, sediment verimi üzerine etkilerini incelemek amaciyla yürütülmüş̧ür. Sediment verimi Modifiye Üniversal Toprak Kaybı Eşitliği (MUSLE) denklemi kullanılarak 25 yıllık bir dönem için tahmin edilmiştir. En fazla ve en az sediment verimi sırasıyla 1980 ve 1997 yıllarında hesaplanmıştır. Meteorolojik ve hidrolojik kuraklık, tarihsel yağış ve akış verileri kullanılarak Standardize Edilmiş Yağış İndeksi (SPI) ile tespit edilmiştir. Çalıșma süresinin 10 yılı meteorolojik olarak kurak ve 15 yılı yağıșlı geçerken, hidrolojik olarak 14 yılı kurak, 11 yılı yağışlı geçmiştir. Meteorolojik olarak kurak ve yağışlı yıllarda sediment verimi sırasıyla 6920.7 ton ve 18068.2 ton olarak hesaplanmıştır. Hidrolojik olarak kurak ve yağışlı yıllarda sediment verimi sırasıyla 7417.8 ton ve 21489.2 ton olarak hesaplanmıştır. Hesaplanan sediment verimi, meteorolojik ve hidrolojik yağışlı ve aynı zamanda meteorolojik ve hidrolojik kurak şartlar altında benzer bulunmuştur. Kuraklık, çalışma alanındaki sediment verimini düşürmüştür.

Anahtar Kelimeler: MUSLE; CBS; Kuraklık; Sediment verimi; Havza 


\section{Introduction}

Drought and wet conditions may affect the sediment amount. The suspended sediment loads in a stream are the results of erosion and transportation process. Sediment yield might increase or decrease during drought seasons. Drought influences erosion primarily through changes in the amount and intensity of rainfall, which associated with reduction of cover vegetation (Schumm 1977). These two factors describe the erosion response to drought. The reduction of rainfall during dry season reduces the erosion; moreover it reduces cover vegetation and the landscape becomes more vulnerable to erosion.

In order to understand which is the most controlling factor on sedimentation in drought condition, several studies has been conducted. Giakoumakis \& Tsakiris (1997) used continuous simulation model with the reconnaissance estimation of sediment yield from a hydrological basin to describe drought effect on sediment yield. In their study, sediment yield estimations were found higher during the wet period following a drought period. Pruski \& Nearing (2002) used WEPP model to find a relation between changes of precipitation and their significant implications on runoff, soil erosion, and conservation planning. In this study, erosion increased approximately $1.7 \%$ for each $1 \%$ change in annual rainfall. Rainfall amounts and intensities were found as the most direct and important factor on changes of erosion under various climate. Nearing et al (2005) investigated the response of seven soil erosion models using a few basic precipitation and vegetation data under humid and semiarid watersheds. They indicated that soil erosion is likely to be more affected by rainfall and cover vegetation than runoff, though both are likely impacted in similar ways. Nunes et al (2008) conducted a research to estimate the effect of climate change on water resources, vegetation productivity and erosion. This was done by analyzing the sensitivity of these variables to varying degrees of temperature change, rainfall (reduced by up to $40 \%$ ) and atmospheric $\mathrm{CO}_{2}$ concentrations. The SWAT watershed model was applied to 18 large watersheds in two contrasting regions of Portugal (humid and semiarid regions); incremental changes to climate variables were simulated using a stochastic weather generator. The main results indicated that, water runoff is highly sensitive to the trend of climate change. For the milder rainfall changes, soil erosion showed a significant increasing trend in the wheat fields (up to $150 \%$ in the humid watersheds). The common agreement of these studies is that the rainfall factor dominates and erosion tends to decrease with decreasing annual rainfall. This suggests that drought is associated with periods of low sediment yield. But the effects of drought on vegetation and sedimentation are nonlinear. The results of numerous plot studies indicated that vegetative cover is the dominant factor controlling erosion, particularly during drought conditions (Dadkah \& Gifford 1980; Wood et al 1987; Blackburn et al 1992; Gutierrez \& Hernandez 1996). These studies indicate that the loss of cover vegetation leaves soils so vulnerable to erosion that even with decreases rainfall erosivity during drought seasons, erosion rates increase dramatically. However, it is not clear that drought effect on sediment yield at watershed scale due to watershed complexity.

Dodangeh at al (2011) conducted a research to consider for hydrological drought analysis at 26 selected stations out of 41 stream flow gauging stations located at the north of Iran. The study area was found heterogeneous and therefore Fuzzy Cluster Analysis (FCA) algorithm was applied to divide being homogenous subregions. Two regions were identified as the result of FCA analysis and the L-Moment analysis. One region was found homogenous and the Generalized Logistic (GLO) distribution was selected for this region. A study related to hydrological drought by using SPI were conducted in the southern Cordoba Province in Argentina to analyze the potential of the SPI as a tool for monitoring flood risk. This study indicated that the SPI satisfactorily explains the development of conditions leading up to the three main flood events to occur in the region during the past 25 years (Seiler et al 2002). The numerous studies in Turkey were used to describe drought with the help of SPI method (Yurekli \& Kurunc 2006; Yurekli \& Anl1 2008; Anlı et al 2009; Yurekli et al 2009; Yurekli et al 2010; Yurekli et al 2010; Yurekli et al 2012).

Information on the sediment yield at the outlet of a river basin is providing a useful perspective to predict the rates of erosion and soil loss in the watershed upstream. In many countries, such measurements were conducted in some research basins. These research activities needs time and costs. Some empirical equation or models produced from these studies, and these models give some advantages as time and costs. The empirical models are widely used for computing the amount of potential soil erosion and sediment yield. Empirical models such as USLE (Universal Soil Loss Equation), MUSLE (Modified Universal Soil Loss Equation) and RUSLE (Revised Universal Soil Loss Equation) provide useful information to predict sediment amount from outlet. Many researchers have conducted some research to evaluate the MUSLE under different conditions for different purposes around the world (Asokan 1981; Nicks et al 1994; Banasik \& Walling 1996; Kinnel 2001; Erskine et al 2002; Sadeghi 2004; Cambazoglu \& Gogus 2004; Mishra et al 2006; Sadeghi et al 2007; Pandey et al 2009). 
Oğuz et al (2011) stated that the $K$ value which is one of MUSLE equation factors is greatly influenced by land slope. In their study, to describe desertification potential in a rural watershed they compared some soil properties in two slope groups (mild to moderate and moderate to steep) with the help of coefficient of variation and fractal dimension of spatial variation. In the study, they found higher fractal coefficients in steep slopes than mild slope and high fractal coefficients values expected to be short-range variation. Generally higher CV values and lower $\mathrm{D}$ values occurred in moderate to steep slopes, indicating greater desertification potential.

Yurekli \& Ozturk (2000) calculated erosion index of Uğrak watershed according to total kinetic energy from 1978 to 1998 years. Yearly erosive index values of the watershed varied between 0.40 and 24.16 MJ.cm/ha.h.

Uğrak watershed is a research basin and rainfall and runoff characteristics were investigated for 25 years period. The storm runoff volume and peak runoff parameters are required for MUSLE models and the mentioned parameters were directly obtained from research findings of the watershed.

In the present study, we investigated the effect of drought on sediment yield in a small agricultural watershed. The objective of this study is to compare the sediment yields in meteorological drought and hydrological drought conditions. This was done by history of meteorological and hydrological data and estimated sediment data by MUSLE.

\section{Material and Methods}

The present study took place at the Uğrak watershed in Tokat region of North Central Anatolia. The geographical area of the watershed is approximately 700 ha with an elevation ranging from 1292.5 to 1485.0 $\mathrm{m}$ above mean sea level (Figure 1). Some of the other geometric characteristics of the catchment area are as listed in Table 1. The average rainfall is $483.6 \mathrm{~mm}$ and minimum and maximum temperature is varying from 3.3 to $17.8^{\circ} \mathrm{C}$. The overall climate of the area is semiarid. The soils, Entisols and Inceptisols are moderate to well-drained. The watershed contains mild to moderate steep areas with low vegetation densities and/or under cultivation. The areas with $<12 \%$ slopes are mainly cultivated. The major vegetation type in fallow areas is grassland with Graminea and Fabaceae as dominant species, other types being shrubs and meadows. The cultivated areas are relatively large, covering $76.6 \%$ of the catchment and the wheat fallow rotation is common. Some woodland, mostly shrubs with a few trees, covering approximately $6.2 \%$ of the catchment, are scattered about. The natural grassland mostly degraded due to heavy grazing, covers $17.2 \%$ of the area. Daily rainfall and runoff data of the watershed were collected from the three automatic raingauge stations and stream flow gauging station located at the outlet of the study watershed bridge between from 1978 and 2002.

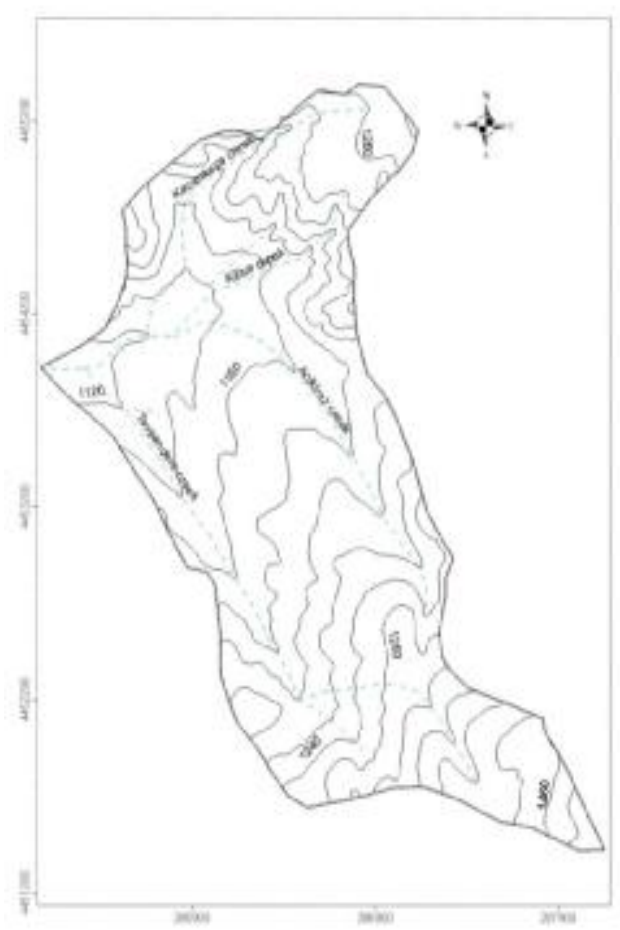

Figure 1- General feature and topographical map of Ugrak watershed

Şekil 1-Uğrak havzasının genel özellik ve topografik haritast

Table 1- Some of the geometric characteristics of the Ugrak watershed

Çizelge 1- Uğrak havzası bazı şekil karakteristikleri

\begin{tabular}{lr}
\hline Area, ha & 700.0 \\
\hline Mean elevation, m & 1292.5 \\
The most top point elevation, m & 1485.0 \\
Outlet elevation above sea level, m & 1100.0 \\
Catchment perimeter, km & 14.0 \\
Average slope, \% & 20.6 \\
Average slope of main river, \% & 4.7 \\
Total length of the river, km & 18.2 \\
Length of the main river, km & 6.7 \\
\hline
\end{tabular}

\subsection{Sediment Yield Prediction (MUSLE)}

The MUSLE was developed from USLE by replacing the rainfall energy factor ( $R$ factor) with a runoff energy factor. The equation was developed using 
individual storm data from 18 basins in Texas and Nebraska and subsequently validated on 102 basins throughout the United States using runoff data generated by the hydrologic component of the SWRRB (Simulator for Water Resources in Rural Basins) model (Williams 1982). The MUSLE increases sediment yield prediction accuracy, eliminates the need for sediment delivery ratios, and is applicable to individual storms. MUSLE is expressed by Williams \& Berndt (1977) as: $Y=11.8(Q q p))^{0.56} \mathrm{KLSCP}$

Where $\mathrm{Y}$ is the sediment yield from an individual storm in metric tons, $\mathrm{Q}$ is the storm runoff volume in $\mathrm{m}^{3}$, qp is the peak runoff rate in $\mathrm{m}^{3} \mathrm{~s}^{-1}$, and $\mathrm{K}$ is soil erodibility factor (t.h. $\mathrm{t}^{-1} \mathrm{~m}^{-1}$ ), LS is topographic factor (dimensionless), $\mathrm{C}$ is crop factors (dimensionless) and finally $\mathrm{P}$ is erosion control practice factor (dimensionless) similar to the USLE model (Williams \& Berndt 1977). MUSLE is used to predict sediment yield on a single storm basis, but it can also be used to predict sediment yield on annual basis with Equation 2 (Simons \& Senturk 1992; Cambazoglu \& Gogus 2004).

$A s=\frac{Q a(0.01 Y s 100+0.01 Y s 50+0.02 Y s 25+0.06 Y s 10+0.4 Y s 2)}{0.01 Q v 100+0.01 Q v 50+0.02 Q v 25+0.06 Q v 10+0.4 Q v 2}$

Where As is the annual sediment yield, and Qa is the average annual water yield, and Ys and Qv are single storm event sediment yield and water yield with corresponding return periods, respectively.

Soil erodibility factor was estimated using the Equation 3 given by Foster et al (1991).

$100 \mathrm{~K}=2.1 \mathrm{M}^{1.14} 10^{-4}(12-a)+3.25(b-2)+2.5(c-3)$

Where $\mathrm{M}[($ silt + very fine sand $)(100$ - clay $)]$ is particle size parameter, $a$ is percent organic matter, $b$ is soil structure code and $\mathrm{c}$ is soil permeability class.

The slope length factor (L) was calculated with the help of Equation 4 (Mc Cool et al 1987).

$L=(\lambda / 22.1)^{m}$

Where $\mathrm{L}$ is slope length factor, which is field slope length $(\mathrm{m}), \mathrm{m}$ is a coefficient that depends on slope steepness, being 0.5 for slopes exceeding $5 \%, 0.4$ for $4 \%$ slopes and 0.3 for slopes less than $3 \%$. The percent slope was determined from DEM with the help of Equation 5.

$S=10.8 \sin \theta+0.03 \quad \mathrm{~s}<9 \%, \quad \mathrm{~S}=16.8 \sin \theta-0.05 \mathrm{~s} \geq 9 \% \quad$ (5)

Where $s$ is slope steepness factor and $\theta$ is slope angle in degree.

The cover and management factor ( $\mathrm{C}$ factor) represents a combined effect of interrelated cover and management variables. $\mathrm{C}$ values derived from local research findings for each land use. The support practice factor ( $\mathrm{P}$ factor) represents a combined effect of support practices and management variables. They are also known as structural methods for controlling erosion. In an area, if conservation practices are not followed $\mathrm{P}$ value should assign as 1 .

\subsection{The Method of L-Moments}

To obtain the sediment and water yield with corresponding return periods in the watershed, we used the distributions of Normal, 2-parameter Log-Normal, Extreme Value Type I, Generalized Logistic, Generalized Pareto, Generalized Extreme Value, 3parameter Log Normal. The parameter estimation of the distributions taken into account in the study was obtained from L-moment approach as defined by Hosking and Wallis (1997). L-moments are linear combinations of probability weighted moments (PWM). Greenwood et al (1979) summarizes the theory of PWM and defined as;

$\beta_{r}=E\left\{X[F x(X)]^{r}\right\}$

Where $\beta_{\mathrm{r}}$ is the $\mathrm{r}^{\text {th }}$ order PWM and $\mathrm{F}_{\mathrm{x}}(\mathrm{X})$ is the cumulative distribution function (cdf) of Hosking \& Wallis (1997) defined unbiased sample estimators of PWMs as $\left(b_{\mathrm{i}}\right)$ and, obtained unbiased sample estimators of the first four L-moments by PWM sample estimators. Unbiased sample estimates of the PWM for any distribution can be computed from;

$b_{r}=n^{-1} \sum_{j=1}^{n-r} \frac{\left.{ }_{r}^{n-j}\right]}{\left.{ }_{r}^{n-1}\right]} X_{J}$

Where $\mathrm{X}_{\mathrm{j}}$ is an ordered set of observations $\mathrm{x}_{1} \leq \mathrm{x}_{2} \leq \mathrm{x}_{3}$ $\leq \ldots \mathrm{x}_{\mathrm{n}}$. For any distribution the first four L-moments are easily computed from PWM using;

$\lambda_{1}=b_{1} \quad \lambda_{2}=2 b_{2}-b_{1}$

$\lambda_{3}=6 b_{3}-6 b_{2}+b_{1}$

$\lambda_{4}=20 b_{4}-30 b_{3}+12 b_{2}-b_{1}$

Sankarasubramanian \& Srinivasan (1999) defines the L-moment ratios (L-coefficient of variation, Lskewness and L-kurtosis, respectively)

$\tau_{2}=\frac{\lambda_{2}}{\lambda_{1}}, \tau_{3}=\frac{\lambda_{3}}{\lambda_{2}} \tau_{4}=\frac{\lambda_{4}}{\lambda_{2}}$

The goodness-of-fit-test based on the KolmogorovSmirnov approach given in Haan (1977) was used to select the best distribution fit to the sediment and water yield data.

\subsection{Standardized Precipitation Index (SPI) Algorithm}

In our study, the Standardized Precipitation Index (SPI) approach was used to determine sediment yield in wet and drought periods. The SPI developed by McKee et al (1993) is a way of measuring drought based only on precipitation. Although the SPI approach was originally developed to monitor drought from precipitation, but in the study the SPI was used in predicting wet and drought periods based on both precipitation and stream flow. The SPI are used to monitor conditions on a 
variety of time scales. Technically, the SPI is the number of standard deviations that the observed value would deviate from the long-term mean, for a normally distributed random variable. The SPI have some advantages for the following reason. Precipitation is only variable in the SPI calculation. Therefore, this index can be applied in regions where the availability of climatic variables limits the use of other wellaccepted indices as Palmer Drought Index (PDSI). SPI, which has a wide spectrum of time scales, make this index more flexible for both short-term and long-term drought monitoring (Edwards \& McKee 1997). The SPI algorithm is conceptually equivalent to $\mathrm{z}$-score commonly used in statistic:

$S P I=\frac{P_{i}-\sum_{i=1}^{n} P_{i} / n}{\sigma_{p}}$

Where SPI is represent the standardized precipitation index, $\mathrm{P}_{\mathrm{i}}$ is rainfall for a given period, $\mathrm{n}$ is the total length of record and $\sigma_{\mathrm{p}}$ is standard deviation.

It is known that rainfall is typically positively skewed. Therefore, the precipitation data should be transformed a more normal or Gaussian symmetrical distribution to use the above z-score relationship (SPI). McKee et al $(1993 ; 1995)$ and Komuscu (1999) implied that the long-term rainfall data sets must first be normalized to determine SPI belonging to the data sets. The prevalent conviction related to the transformation of monthly rainfall is that the gamma distribution is applied. Thorn (1966) stated that monthly rainfall generally fit to the gamma distribution. Guttman (1999) examined the impact of six distributions on SPI and recommended that Pearson Type III distribution is the best way to normalize long-term data when calculating SPI. Edwards and McKee (1997) suggested gamma distribution with two parameters to transform the precipitation data.

Sediment yields in meteorological and hydrological drought and wet conditions were compared using t-test.

\section{Results and Discussion}

For estimating of soil erodibility factor for each soil series, soil samples were taken from the topsoil. The calculated $\mathrm{K}$ values using the Equation 3 are presented in Table 2. In the study area, the calculated $\mathrm{K}$ values varied between 0.03 and 0.25 t.h.t $\mathrm{t}^{-1} \mathrm{~m}^{-1}$. The most dominated soil series were Tekneli and Tavşandere soil series, and their $\mathrm{K}$ factors were 0.03 and 0.25 , respectively. The spatial distribution of soil erodibility values are given in Figure 2.

Topographic factor (LS) was derived from DEM by multiplying the $\mathrm{L}$ and $\mathrm{S}$ factors. An increase in LS values show that the increasing rate of soil erosion. The LS values in the Uğrak watershed varied between 0 and
8.5 and its spatial distribution was presented in Figure 3.

Table 2- Soil erodibility factor for soil series Çizelge 2- Toprak serileri aşınıma duyarlılık faktörü

\begin{tabular}{llll}
\hline Soil Series & \multicolumn{2}{c}{ Area } & K Factor \\
\cline { 2 - 3 } & $\mathrm{km}^{2}$ & $\%$ & \\
\hline Tekneli & 2.33 & 33.29 & 0.03 \\
Semertas & 1.36 & 19.43 & 0.21 \\
Acikiraz & 0.95 & 13.57 & 0.20 \\
Tavsandere & 2.15 & 30.71 & 0.25 \\
Ugrak & 0.21 & 3.00 & 0.20 \\
Total & 7.00 & 100.00 & \\
\hline
\end{tabular}

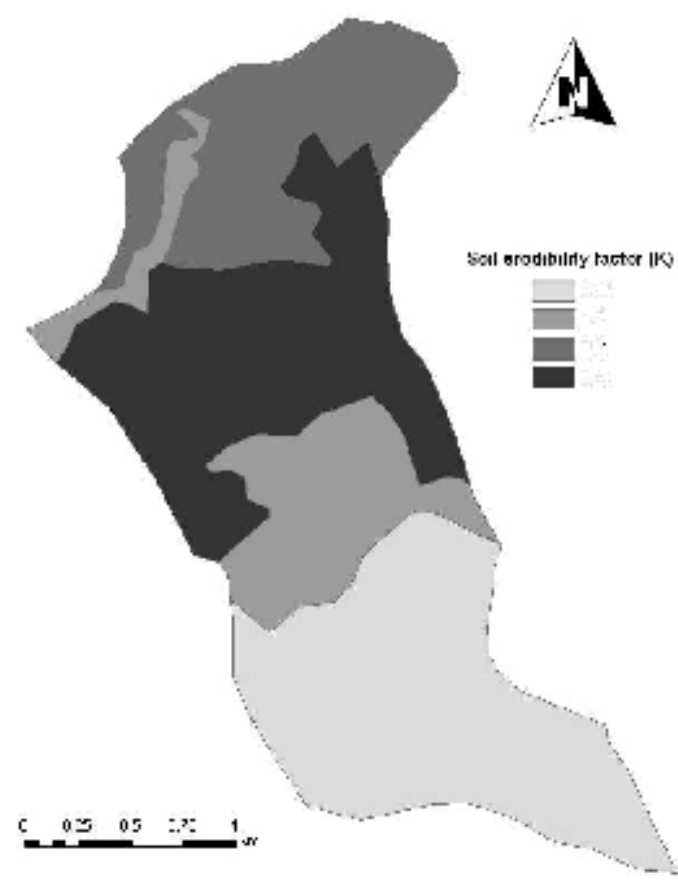

Figure 2- Distribution of soil erodibility factor in the study watershed

Şekil 2-Çalışma havzası aşınıma duyarlılık dağılımı

The factors of $\mathrm{C}$ were assigned to different land use types (Table 3) and were presented spatially in Figure 4. There are 3 main land use types as cropland, grassland and shrub in the Uğrak watershed. The crop management factors for cropland were obtained experimental plots (Oğuz et al 1998). On the other hand, the crop management factors for grassland and shrubs were used by previously proposed values of Çanga (1995).

In the study area, conservation practices are not followed. Hence, the conservation practice factor of 1 was assigned. 


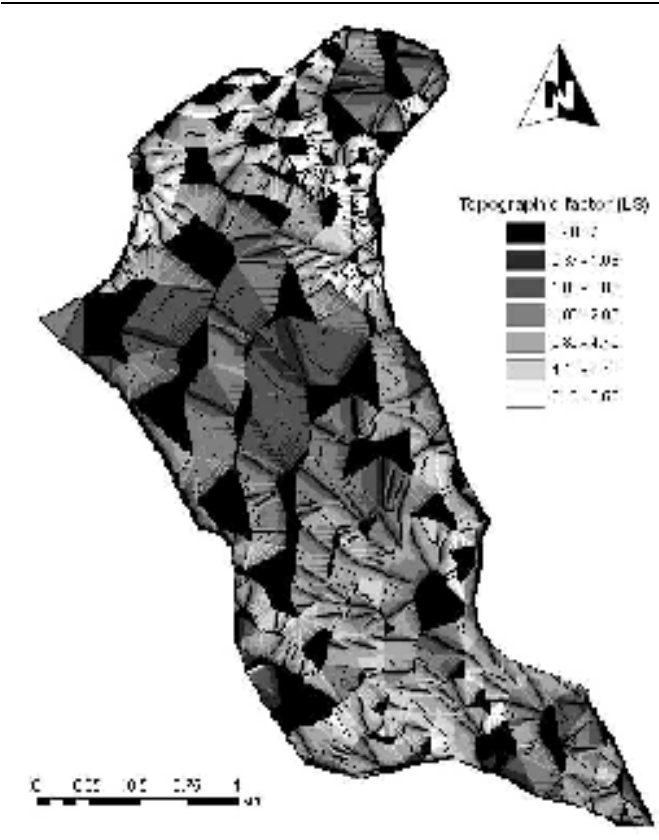

Figure 3- Distribution of topographic factor in the study watershed

Şekil 3-Çalışma havzası topoğrafik faktör dağılımı

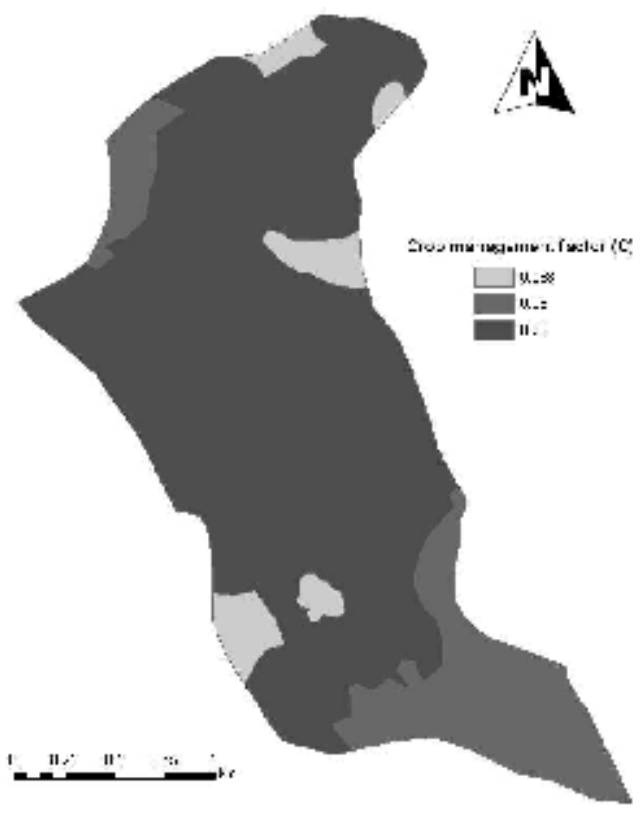

Figure 4- Distribution of crop management factor in the study watershed

Şekil 4-Çalışma havzası bitki yönetim faktör dağılımı
Table 3- Crop management factor for land use/land cover classes

Çizelge 3- Arazi kullanım türlerine ait bitki yönetim faktörleri

\begin{tabular}{llll}
\hline Landuse & \multicolumn{2}{c}{ Area } & C Factor \\
\cline { 2 - 3 } & $\mathrm{km}^{2}$ & $\%$ & \\
\hline Shrub & 0.32 & 4.57 & 0.038 \\
Grassland & 1.22 & 17.43 & 0.050 \\
Dry farming & 5.46 & 78.00 & 0.280 \\
Total & 7.00 & 100.00 & \\
\hline
\end{tabular}

Finally KLSCP values were multiplied in ArcGIS environment and the result is presented spatially in Figure 5. Average KLSCP value was found 0.07 and some statistical evaluations were given in Table 4. In order to calculate the sediment yield in Uğrak watershed by MUSLE, average KLSCP value was taken as 0.07 .

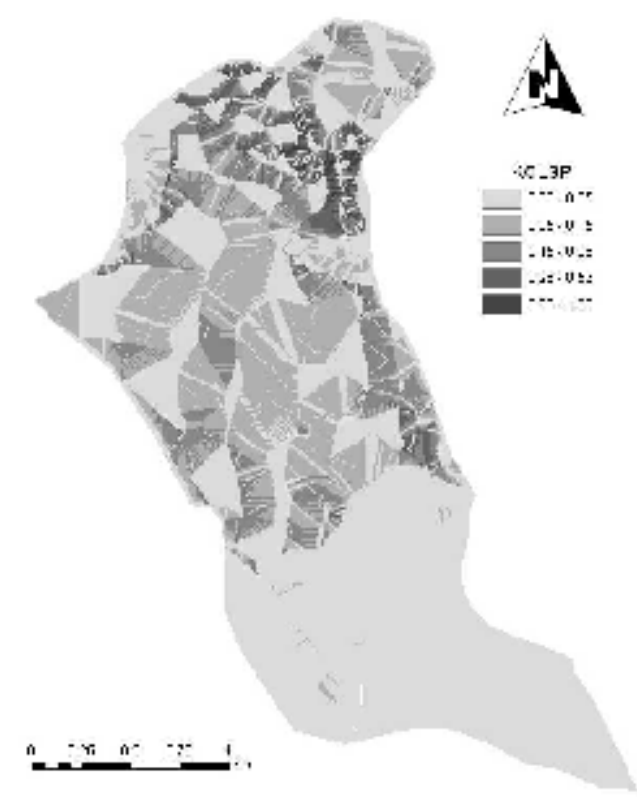

Figure 5- Distribution of multiplied KCLSP factors in the study watershed

Şekil 5-Çalışma havzasında KCLSP factor çarpımlarının dăğlımı

Table 4- Statistical distribution of KLSCP values Cizelge 4- KLSCP değerlerinin istatistiksel dağılımı

\begin{tabular}{lccccr}
\hline $\begin{array}{l}\text { Statistical } \\
\text { parameters }\end{array}$ & Min & Max & Mean & STDV & CV, \% \\
\hline K & 0.03 & 0.25 & 0.18 & 0.08 & 44.44 \\
LS & 0.00 & 8.50 & 1.90 & 2.00 & 105.26 \\
C & 0.038 & 0.28 & 1.90 & 2.00 & 105.26 \\
KLSCP & 0.00 & 1.38 & 0.07 & 0.10 & 142.86 \\
\hline
\end{tabular}


The average long-term discharge of the Ugrak watershed was $55.64 \mathrm{~mm} /$ year. Fourteen storms, for which an accurate and a reported data were available, were selected in the present study and detailed information is shown in Table 5 (Oguz \& Balcin 2003).

The selected storms of Uğrak watershed were used in applying Equation 1, and the results are presented in Table 5. The next step to predict annual sediment yield in the watershed were applied Equation 2. For this purpose the weighted storm yield was multiplied by the ratio of annual water yield to single storm sediment yield and water yield at some return periods (Table 6.). Table 6 is predicted from the Log-Normal distribution. The Log-Normal distribution among the distributions used in this study had the most minimum KolmogorovSmirnov test value than the other distributions. Therefore, the Log-Normal distribution was selected as best-fit distribution in order to obtain the sediment and water yield with corresponding return periods. The computation of annual sediment yield after using MUSLE was presented in Table 7.

In this study, annual total rainfall and flow were used to determine meteorological and hydrological drought in the watershed. For this purpose we used Standardized Precipitation Index (SPI) to rainfall and flow between 1978-2002 years for 25 years period. In this period, 10 years drought and 15 years wet were found as meteorological and 14 years drought and 11 years wet were experienced as hydrological (Table 7). As rainfall and stream flow data were skewed, the mentioned data was transformed by taking logarithm of the data set. Thus, the rainfall and stream flow data were transformed a more normal or Gaussian symmetrical distribution to use the above z-score (SPI) relationship.

Table 5- Selected storms and estimated sediment yield by MUSLE in Ugrak watershed Çizelge 5- Uğrak havzası seçilmiş akımları ve MUSLE ile hesaplanmış sediment verimi

\begin{tabular}{|c|c|c|c|c|c|c|c|c|}
\hline \multirow[t]{3}{*}{ No } & \multirow[t]{3}{*}{ Storm date } & \multicolumn{2}{|c|}{ Rainfall } & \multicolumn{4}{|c|}{ Runoff } & \multirow{3}{*}{$\begin{array}{c}\text { Estimated } \\
\text { sediment yield } \\
\text { (ton) }\end{array}$} \\
\hline & & \multirow{2}{*}{$\begin{array}{l}\text { Depth } \\
\text { (mm) }\end{array}$} & \multirow{2}{*}{$\begin{array}{c}\text { Duration } \\
(h)\end{array}$} & \multicolumn{2}{|c|}{ Volume } & \multirow{2}{*}{$\begin{array}{c}\text { Peak flow, } \\
\left(m^{3} s^{-1}\right)\end{array}$} & \multirow{2}{*}{$\begin{array}{l}\text { Duration } \\
\text { (h) }\end{array}$} & \\
\hline & & & & $\left(m^{3}\right)$ & $(\mathrm{mm})$ & & & \\
\hline 1 & 21.05 .1979 & 14.6 & 1.42 & 1750 & 0.25 & 1.320 & 2.33 & 63.18 \\
\hline 2 & 23.06 .1979 & 24.9 & 1.83 & 4550 & 0.65 & 2.540 & 2.50 & 155.66 \\
\hline 3 & 12.07 .1979 & 19.1 & 0.67 & 2520 & 0.36 & 1.560 & 2.50 & 85.10 \\
\hline 4 & 08.05 .1980 & 10.6 & 3.71 & 3080 & 0.44 & 2.070 & 2.50 & 111.56 \\
\hline 5 & 11.09 .1981 & 16.2 & 0.5 & 1190 & 0.17 & 0.990 & 2.50 & 43.34 \\
\hline 6 & 30.05 .1983 & 11.1 & 0.58 & 3430 & 0.49 & 1.250 & 2.50 & 89.33 \\
\hline 7 & 31.05 .1983 & 8.5 & 1.92 & 980 & 0.14 & 0.740 & 1.83 & 33.02 \\
\hline 8 & 16.05 .1985 & 1.3 & 0.25 & 140 & 0.02 & 0.082 & 1.67 & 3.24 \\
\hline 9 & 14.06 .1986 & 14.5 & 2.08 & 4690 & 0.67 & 3.480 & 2.00 & 188.85 \\
\hline 10 & 04.06.1989 & 3.6 & 0.42 & 420 & 0.06 & 0.280 & 1.83 & 11.92 \\
\hline 11 & 09.07.1992 & 16.5 & 0.67 & 770 & 0.11 & 0.268 & 2.67 & 16.34 \\
\hline 12 & 25.05 .1993 & 14.8 & 3.25 & 840 & 0.12 & 0.286 & 4.17 & 17.79 \\
\hline 13 & 07.10 .1993 & 11 & 0.75 & 420 & 0.06 & 0.311 & 4.25 & 12.65 \\
\hline 14 & 12.09 .2002 & 19.9 & 0.75 & 980 & 0.14 & 0.416 & 3.00 & 23.92 \\
\hline
\end{tabular}

Table 6- Return periods for single storm sediment yield and water yield (for non-exceedance probability) Çizelge 6-Sediment ve su verimi için bireysel fırtınaların tekerrür süreleri (aşılmama olasılığına göre)

\begin{tabular}{lccccc}
\hline \multirow{2}{*}{ Series } & \multicolumn{5}{c}{ Return periods, years } \\
\cline { 2 - 5 } & 2 & 10 & 25 & 50 & 100 \\
\cline { 2 - 5 } Ys, ton & 1775.66 & 537.98 & 347.48 & 261.99 & 203.22 \\
Qv, $\mathrm{m}^{3}$ & 1230.04 & 319.99 & 195.46 & 142.16 & 106.75 \\
\hline
\end{tabular}


Yağışlı ve Kurak Yıllarda Sediment Veriminin Değişim Analizi, Oğuz

Table 7- Rainfall, flow, runoff, sediment yield and SPI values in Ugrak watershed

Çizelge 7- Ŭgrak havzasında yă̆ış, akış, yüzey akış, sediment verimi ve SPI değerleri

\begin{tabular}{|c|c|c|c|c|c|c|}
\hline \multirow[t]{2}{*}{ Years } & \multirow[t]{2}{*}{ Rainfall, $(\mathrm{mm})$} & \multirow[t]{2}{*}{ Flow, $\left(m^{3}\right)$} & \multirow[t]{2}{*}{ Runoff, $\left(m^{3}\right)$} & \multirow{2}{*}{$\begin{array}{c}\text { Sediment yield } \\
\text { (ton) }\end{array}$} & \multicolumn{2}{|c|}{ SPI Values } \\
\hline & & & & & Rainfall & Flow \\
\hline 1978 & 481.5 & 184380 & 3220 & 4691.4 & -0.026 & -0.898 \\
\hline 1979 & 518.5 & 116760 & 4008 & 5838.8 & 0.433 & -1.194 \\
\hline 1980 & 528.1 & 733880 & 19653 & 28633.0 & 0.551 & 1.509 \\
\hline 1981 & 496.9 & 833490 & 11649 & 16972.4 & 0.165 & 1.945 \\
\hline 1982 & 505.1 & 208810 & 2088 & 3042.6 & 0.267 & -0.791 \\
\hline 1983 & 378.3 & 626360 & 3582 & 5218.4 & -1.304 & 1.038 \\
\hline 1984 & 591.1 & 588910 & 9823 & 14312.2 & 1.332 & 0.874 \\
\hline 1985 & 341 & 255850 & 6026 & 8779.4 & -1.767 & -0.585 \\
\hline 1986 & 535.4 & 461860 & 3407 & 4963.4 & 0.642 & 0.317 \\
\hline 1987 & 414.4 & 373800 & 134 & 195.5 & -0.857 & -0.069 \\
\hline 1988 & 594.8 & 647220 & 13242 & 19292.6 & 1.378 & 1.129 \\
\hline 1989 & 448 & 250880 & 6510 & 9484.8 & -0.441 & -0.607 \\
\hline 1990 & 607.2 & 605290 & 19209 & 27987.1 & 1.531 & 0.945 \\
\hline 1991 & 499.8 & 274820 & 7327 & 10674.7 & 0.201 & -0.502 \\
\hline 1992 & 514.5 & 314020 & 10074 & 14677.7 & 0.383 & -0.330 \\
\hline 1993 & 537.6 & 567210 & 31780 & 46302.3 & 0.669 & 0.779 \\
\hline 1994 & 343.2 & 612290 & 18381 & 26780.2 & -1.739 & 0.976 \\
\hline 1995 & 546.3 & 650790 & 12851 & 18723.2 & 0.777 & 1.145 \\
\hline 1996 & 554.4 & 258790 & 8814 & 12841.9 & 0.877 & -0.572 \\
\hline 1997 & 365.4 & 63910 & 117 & 170.0 & -1.464 & -1.426 \\
\hline 1998 & 521.2 & 396970 & 18667 & 27196.7 & 0.466 & 0.033 \\
\hline 1999 & 459 & 113820 & 1225 & 1784.8 & -0.305 & -1.207 \\
\hline 2000 & 499.6 & 350000 & 13428 & 19564.6 & 0.198 & -0.173 \\
\hline 2001 & 328.3 & 14350 & 362 & 526.9 & -1.924 & -1.643 \\
\hline 2002 & 480.1 & 231700 & 7945 & 11575.6 & -0.043 & -0.691 \\
\hline
\end{tabular}

Estimated sediment yield by MUSLE were grouped meteorologically and hydrological drought and wet conditions in Figure 6. Sediment yields in meteorological and hydrological drought and wet conditions were compared using t-test and presented in Table 8. The estimated mean sediment yields were found similar in meteorological and hydrological wet conditions, whereas it was significantly different in meteorological and hydrological drought conditions. Changes in rainfall, erosion and as well as in the amount of cover vegetation result in further changes in both hydrology and soil erosion. These interactions may not be accurately represented by watershed complexity.

Increasing precipitation and stream flow often result to increasing erosion as well as the amount of suspended sediment in a watershed. In Uğrak watershed we concluded that the drought decreases sediment yield dramatically. Same result was found in the Selenga River watershed within the Yenisey River watershed in southern East Siberia (Korytny et al 2003). In that study, an increase in precipitation was observed by an increase in suspended sediment load. 


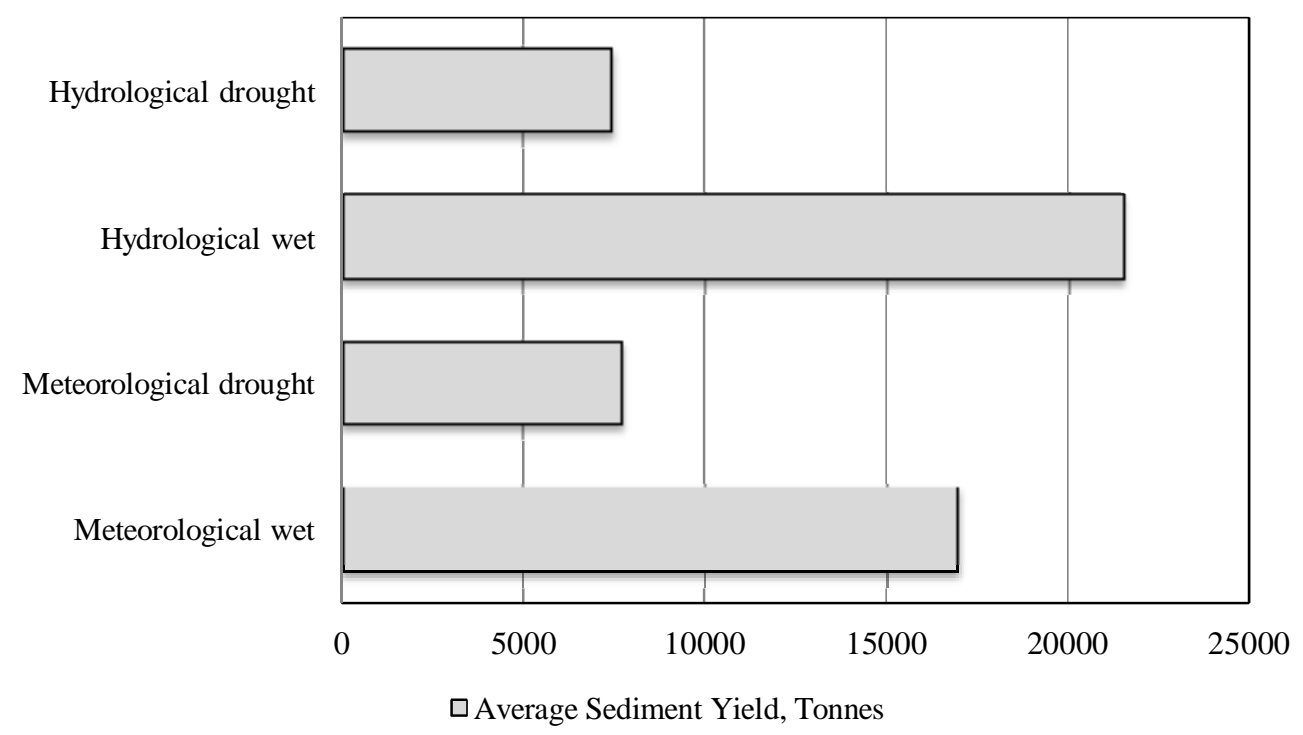

Figure 6- Sediment yield in drought and wet periods in Ugrak watershed Şekil 6-Kurak ve yağışlı dönemlerde Uğrak havzast sediment verimi

Table 8- Average estimated sediment yield of different drought conditions

Çizelge 8- Farklı kuraklık koşullarında hesaplanmış ortalama sediment verimi

\begin{tabular}{lc}
\hline Drought & $\begin{array}{c}\text { Average Estimated } \\
\text { Sediment Yield (ton) }\end{array}$ \\
\hline Meteorological drought & $6921^{\mathrm{b}}$ \\
Meteorological wet & $18068^{\mathrm{a}}$ \\
Hydrological drought & $7418^{\mathrm{b}}$ \\
Hydrological wet & $21489^{\mathrm{a}}$ \\
\hline
\end{tabular}

As contrast, at four watersheds, the Edwards Plateau Land Resource Area of Texas in USA, were combined with the results of three prior surveys to assess the effect of the 1950s drought on sediment yield (Dunbar et al 2010). It was concluded that drought increased sediment yield dramatically. This suggests that the reduction of cover vegetation during the drought period become the rangeland so vulnerable to erosion. This factor outweighed the reduction in rainfall erosivity. In Uğrak, watershed land use is mostly dry farming (Table 3). Limited perennial vegetation and limited reduction of cover vegetation had a limited effect on sediment yield at drought conditions in the watershed.

Because of having different watershed characteristics, drought effect on sediment yield is different for every watershed. Therefore, more studies should be done to determine the effect of drought and wet conditions on sediment yield in different watersheds throughout the world.

\section{Conclusion}

Average rainfall and sediment yield were found as $403.9 \mathrm{~mm}$ and 6920.7 ton for the meteorological drought years and $536.7 \mathrm{~mm}$ and 18068.2 ton for the meteorological wet years, respectively. These values were measured as $30.7 \mathrm{~mm}$ and 7417.8 ton for the hydrological drought years and $87.3 \mathrm{~mm}$ and 21489.2 ton for the hydrological wet years. The sediment yields were found similar within the meteorological and hydrological wet conditions and at the same time within the meteorological and hydrological drought conditions. Average sediment yield was found statistically significant at meteorological and hydrological drought and wet years. In Uğrak watershed, cultivated lands cover larger areas than grassland and shrub areas therefore much more soil erosion occurred in wet years in the watershed. In the study, negative correlation between drought and sediment yield was also found.

\section{References}

Anlı A S, Apaydın H \& Öztürk F (2009). Regional frequency analysis of the annual maximum precipitation observed in Trabzon province. Tarım Bilimleri Dergisi 15: (3) 240248

Asokan K (1981). Runoff and sediment yield from Bino subwatershed of Ramganga catchment. Msc Thesis, Govind Ballabh Pant University (Unpublished), India 
Banasik K \& Walling D E (1996). Predicting sediment graphs for a small agricultural catchment. Nordic Hydrology 27(4): 275-294

Blackburn W H, Pierson F B, Hanson C L, Thurow T L \& Hanson A L (1992). The spatial and temporal influence of vegetation on surface soil factors in semiarid rangelands. Transactions of the ASAE 35: 479-486

Canbazoğlu M K \& Gogus M (2004). Sediment yields of basins in the Western Black Sea Region of Turkey. Turkish Journal of Engineering and Environmental Sciences 28: 355-367

Canga M R (1995). Toprak ve Su Koruma. Ankara Üniversitesi Ziraat Fakültesi Yayınları: 1386, Ders kitabı: 400, Ankara

Dadkah M \& Gifford G F (1980). Influence of vegetation, rock cover and trampling on infiltration rates and sediment production. Water Resources Bulletin 16: 979986

Dodangeh Smaeel, Sattari M T \& Seçkin N (2011). Regional frequency analysis of minimum flow by L-Moments method. Tartm Bilimleri Dergisi 17: 43-58

Dunbar J A, Allen P M \& Bennett S J (2010). Effect of multiyear drought on upland sediment yield and subsequent impacts on flood control reservoir storage. Water Resources Research 46: 1-12

Edwards D C \& McKee T B (1997). Characteristics of 20th century drought in the United States at multiple time scales. Climatology Report 97-2, Colorado State University, Fort Collins, CO

Erskine W D, Mahmoudzadeh A \& Myers C (2002). Land use effects on sediment yields and soil loss rates in small basins of Triassic sandstone near Sydney NSW Australia. Catena 49: 271-287

ESRI (2009). ArcGIS desktop 9.3 help, Environmental Systems Research Institute (ESRI), http://webhelp.esri.com/arcgisdesktop/9.3/

Foster G R, Mc Cool D K, Renard K G \& Moldenhauer W C (1991). Conversion of the universal soil loss equation to SI metric units. Journal of Soil and Water Conservation 36: $355-359$

Giakoumakis S G \& Tsakiris G P (1997). Meteorological drought effect on sediment yield. Water Resources Management 11: 365-376

Greenwood J A, Landwehr JM, Matalas NC \& Wallis J R (1979). Probability weighted moments: Definition and relation to parameters of several distributions expressible in inverse form. Water Resources Research 15: 10491054

Gutierrez J \& Hernandez I I (1996). Runoff and interril erosion as affected by grass cover in a semi-arid rangeland of northern Mexico. Journal of Arid Environment 34: 287-295

Guttman NB (1999). Accepting the standardized precipitation index: A Calculation algorithm. Journal of the American Water Resources Association 35: 311-322

Haan, C T (1977). Statistical methods in hydrology. Iowa State Uni. Press, Ames, IA
Hosking J R M \& Wallis J R (1997). Regional frequency analysis: An approach based on LMoments. Cambridge University Press, Cambridge, U.K

Kinell P I A \& Risse L M (1998). USLE-M: empirical modeling rainfall erosion through runoff and sediment concentration. Soil Science Society of America Journal 62: $1162-1672$

Kinell P I A (2001). The USLE-M and modeling erosion within catchments. In: Slott D E Mohtar R H Steinardt (Eds) $10^{\text {th }}$ International Soil Conservation Organization Meeting Purdue University-USDA-ARS National Soil Erosion Research Laboratory, USA

Komuscu A U (1999). Using the SPI to analyze spatial and temporal patterns of drought in Turkey. Drought Network News 11: 7-13

Korytny LM, Bazhenova OI, Martianova GN \& Ilyicheva EA (2003). The influence of climatic change and human activity on erosion processes in sub-arid watersheds in southern East Siberia. Hydrological Processes 17: 31813193

Kundzewicz Z W \& Parry M L (2002). Europe, in Climate Change 2001: Impacts, Adaptation, and Vulnerability. Edited by J. McCarthy et al., pp. 641-692, Cambridge Univ. Press, Cambridge, U. K

Mc Cool D K, Foster G R, Mutchler C K \& Meyer L D (1987). Revised slope steepness factor for the universal soil loss equation. Transactions of the AAE 30:(5) 13871396

McKee T B, Doesken N J \& Kleist J (1993). The relationship of drought frequency and duration to time scales. Eighth Conference on Applied Climatology, American Meteorological Society, Anaheim, CA

McKee T B, Doesken N J \& Kleist J (1995). Drought monitoring with multiple time scales. Preprints, $9^{\text {th }}$ Conference on Applied Climatology 15-20 January Dallas Texas American Meteorological Society 233-236

Mishra S K, Tyagi J V, Singh V P \& Singh R (2006). SCS$\mathrm{CN}$ based modelling of sediment yield. Journal of Hydrology 324: 301-322

Nearing, M A, Jetten V, Baffaut C, Cerdan O, Couturier A, Hernandez M, Le Bissonnais Y, Nichols M.H, Nunes J.P, Renschler C.S, Souchère V \& Van Oost K (2005). Modelling response of soil erosion and runoff to changes in precipitation and cover. Catena 61: 131-134

Nicks A D, Williams J R \& Gander G A (1994). Estimating erosion with models having different technologies. Proc. $25^{\text {th }}$ Annual Conference International Erosion Control Associate Reno NV February 15-18 pp. 51-61

Nunes J P, Seixas J \& Pacheco N R (2008). Vulnerability of water resources, vegetation productivity and soil erosion to climate change in Mediterranean watersheds. Hydrological Process Journal 22: 3115-3134

Oguz I, Balcin M \& Senol M (1998). Yozgat yöresinde Üniversal Denklemin K, R, C ve P faktörleri. Toprak ve Su Kaynakları Araştırma Yıllığı 1997. Köy Hizmetleri Genel Müdürlüğü, 106:71-81

Oguz I \& Balcin M (2003). Tokat- Uğrak havzası yağış ve akış karakteristikleri. Toprak ve Su Kaynakları Araştırma 
Sonuç Raporları 2003. T.C. Tarım ve Köy İşleri Bakanlığı, Köy Hizmetleri Genel Müdürlügüü, APK Dairesi Başkanlığı, Toprak ve Su Kaynakları Araştırma Şube Müdürlüğü, Yayın No: 124. Ankara

Oguz I, Ersahin S \& Susam T (2011). Evaluation of Desertification Potential in a Sloping Catchment. Carpathian Journal of Earth and Environmental Sciences 6 (1): $81-88$

Pandey A, Chowdary V M \& Mal B C (2009). Sediment yield modelling of an agricultural watershed using MUSLE, remote sensing and GIS. Paddy and Water Environment 7: $105-113$

Pruski F F \& Nearing M A (2002). Runoff and soilloss responses to changes in precipitation: A computer simulation study. Journal of Soil Water Conservation 57: $7-16$

Sadeghi S H (2004). Aplication of MUSLE in prediction of sediment yield in Iranian Conditions. ISCO 2004-1 $3^{\text {th }}$ Int. Soil Conservation Org. Conference Brisbane

Sadeghi S H R, Mizuyama T \& Miyata S (2007). Is MUSLE apt to small steeply reforested watershed? Journal of Forest Research 12: 270-277

Sankarasubramanian A \& Sirinivasan K (1999). Investigation and comparison of sampling properties of L-Moments and conventional moments. Journal of Hydrology 218: 13-34

Schumm S A (1977). The fluvial system. 338 pp John Wiley, New York

Seiler R A, Hayes M \& Bressan L (2002). Using the standardized precipitation index for flood risk monitoring. International Journal of Climatology 22: 1365-1376

Simons D B \& Şentürk F (1992). Sediment transport technology. Water Resources Publications Littleton Col
Thorn H C S (1966). Some methods of climatological analysis. WMO Techniques Note 81: 8, 16-22

Yurekli K \& Kurunc A (2006). Simulating agricultural drought periods based on daily rainfall and crop water consumption. Journal of Arid Environments 67: 629-640

Yurekli K \& Anlı S A (2008). Analyzing drought based on annual total rainfalls over Tokat province. International Journal of Natural and Engineering Sciences 2: (2) 21-26

Yurekli K, Anlı S A, Karahan G \& Ors I (2009). Drought trend analysis in Karaman province. 1. Ulusal Kurakllk ve Çölleşme Sempozyumu, 113-119, 16-18 Haziran, Konya, Turkiye

Yürekli K \& Öztürk F (2000). Tokat-Uğrak havzasında erozyona sebep olan yağmurların incelenmesi. Tarım Bilimleri Dergisi-Journal of Agricultural Sciences 6 (1): 67-72

Yurekli K, Ünlükara A \& Yıldırım M (2010). Karaman province drought analysis by different approaches. Research Journal of Agricultural Sciences 3: (1) 19-23

Yurekli K, Sattari M H, Anlı A S Hınıs M A (2012). Seasonal and annual regional drought prediction by using datamining approach. Atmosfera 25: (1) 85-105

Williams J R \& Berndt H D (1977). Sediment yield prediction based on watershed hydrology. Transactions of the ASAE 23: 1100-1104

Williams J R (1982). Testing the modified universal soil loss equation. In: Proceedings of the Workshop on Estimating Erosion and Sediment Yield on Rangelands. U.S. Department of Agriculture ARM-W-26, 157-161

Wood J C, Wood M K \& Tromble J M (1987). Important factors influencing water infiltration and sediment production on arid lands in New Mexico. Journal of Arid Environment 12: 111-118 